\title{
An assessment of the Impact of Devolution on Women Empowerment in Nakuru County
}

\author{
${ }^{1}$ David Gichuhi \& ${ }^{2}$ Irene Mwakai Njuguna \\ ${ }^{1}$ Lecturer, Karatina University; ${ }^{2}$ St. Paul's University
}

\begin{abstract}
Women have been grossly marginalized in organs of decision-making and governance structures. The Constitution of Kenya has sought to bridge this gap by providing both women and men the right to equal treatment, including the right to equal opportunities in political, economic, cultural and social spheres. However, gender equality has not been achieved and women are still lagging in terms of decision making processes. The main objective of the study was to detemine the impact of devolution on women empowerment in Nakuru County. The study found that substantive women representation, development of programs and accessibility of services had a positive effect on the women empowerment in Nakuru County. The study also found out that increased accessibility of Services by women influenced women empowerment, this study also concludes that the introduction of development programs had the greatest impact on women empowerment in Nakuru County. The study recommends that more programs targeting women should be introduced as these have the greatest impact on women empowerment. The findings may be used to make conclusions and recommendations.
\end{abstract}

Keywords: Devolution, Representation, Development, Programs, Empowerment, Accessibility

\section{BACKGROUND OF THE STUDY}

Women empowerment aims to raise the abilityof women be able to participate in, contribute to and be able to benefit from development processes so that they can recognise the importance of their contributions, respect their dignity and be able to negotiate for a fairer distribution of the benefits of these development processes(Chen \& Mahmud, 1995). When women are empowered they are able to increase their accessibility to economic resources and opportunities that are available.. However, this access is often hindered by discrimination and persistent gender inequalities. Women's empowerment brings direct benefits to women but also has a strong impact on poverty and growth, and is essential for achieving the Millennium Development Goals (OECD, 2011). According to World Bank (2012) women represent 130 percent of the worlds' poor. They are often paid less than men for their work, with the average wage gap in 2008 being 17 percent. Women face persistent discrimination when they apply for credit for business or self-employment and are often concentrated in insecure, unsafe and low-wage work. Eight out of ten women workers are considered to be in vulnerable employment in sub-Saharan Africa and South Asia, with global economic changes taking a huge toll on their livelihoods (UN Women, 2011). In subsistence economies, women spend much of the day performing tasks to maintain the household, such as carrying water and collecting fuel wood. In many countries women are also responsible for agricultural production and selling. Often they take on entrepreneurial enterprises. In Bangladesh, social, economic and political structures generate norms and practices of women's subordination to men, the consequences of which are women's relative lack of choice and agency in decisions that shape their welfare (Chen \& Mahmud, 1995).

Exclusion of women from the political arena is a global phenomenon. There is a persistent gender gap in politics with an average of only $18.4 \%$ women in the world parliaments (UNDP, 2010). According to the Committee on the Elimination of Discrimination against Women (CEDAW, 1997), real impact interms of decision making can be achived if representation of women goes between 30-35\%. Accordingly, every public forum where issues of public life are decided upon, neither sex should constitute less than 40\% (CEDAW, 1997). According to the United Nations report, only $29.5 \%$ of staff is women in the highest ranks of the UN system (United Nations, 2012). The report acknowledges that the UN wants to get to a situation where it has $50 / 50$ gender balance across the board in the whole organization. Statistics shows that parity will not be achieved until 2034(Inter-Parliamentary Union(2013). The report indicates that in the national parliaments only $20.9 \%$ parliamentarians are female and this is slow growth from $11.6 \%$ in 1995 . The report further shows less than $10 \%$ of parliamentarians in 37 states are women.By then, there were 8 women serving as heads of state and 13 working as heads of government. In addition $17 \%$ of the world's government ministers are women and majority of them in these ministerial roles are responsible for social sectors such as education and health (InterParliamentary Union, 201). 
According to United Nations statistics on local government 10 of the world's 195 capital cities are headed by a woman which is $5.1 \%$ and women councilors are only $20 \%$ of councillors worldwide (United Cities and Local Governments, 2013). In the United Kingdom, it will take 150 years for women to gain equal representation in local government (Centre for Women and Democracy, 2011). According to inter-parliamentary union (2013) 35 countries, including 9 in Africa are supposed to have attained the $30 \%$ benchmark of women in parliament and out of these these 35 countries 29 of the which is $(83 \%)$ have employed the quota system to promote women's participation in politics. In Rwanda, from 1994 to 2003, women's representation in Parliament reached $25.7 \%$ during which a new gender-sensitive constitution was adopted. The dramatic gains for women are a result of specific mechanisms used to increase women's political participation, among them a constitutional guarantee, a quota system, and innovative electoral structures (Powley, 2004). In Kenya, the proportion of women who became parliamentary candidates and MPs for the major political parties has not increased (Awuor, 2013). It shows how women are Grossly Underrepresented, With Only 10.7\% Of Candidates Being Women. The Total Number Of Women Elected In The $10^{\text {th }}$ Parliament Was 16 With 6 Nominated, Bringing To Total 22, The Number Of Women Mps. The Substantial Progress Toward Gender Empowerment Is Supported By Strong Institutional Measures, Including Policy And Budgetary Commitments, Which Seek To Mainstream Gender Equality Within Government Policy-Making (Huggins \&Randell, 2007). According To Awuor (2013) Women In Kenya Continue To Be Marginalized In Many Areas Of Society, Especially In The Sphere Of Leadership And Decision Making. Only 30.9\% Of Those Employed In Kenya's Public Service Are Women, 72\% Of Who Are In The Lower Cadres. Women Hold Only About $10 \%$ Of The Seats In The 11th Parliament (Kamau, 2013). Women Make Up To Over 50\% Of The Worlds Population, They Constituted 16\% Of Mps In The 11th Parliament; 26\% Of Cabinet Secretaries And 13\% Of Members Of The County Assembly. Therefore Enhanced Women Representation Through Devolution Is Essential If Women Are To Have An Impact In The Decision-Making Process (Awuor, 2013).

The Kenya National Policy on Gender and Development (NPGD), 2000 spells out a policy approach of Gender mainstreaming and empowerment of women and clearly states that it is the right of women, men, girls and boys to participate in and benefit equally from the development process. The NPGD provides a framework for mainstreaming gender in all policies, planning and programming in Kenya and puts in place institutional mechanisms to ensure effective implementation. The need for a national policy arose from the government's realisation that without a coherent and comprehensive overall framework for guiding gender mainstreaming within the different sectors and line ministries involved in development, enormous resources may continue to be misplaced. The Department of Gender and Social Development was established in December 2006 following the merger between the Departments of Gender and Social Services. The overall mandate of the Department of Gender and Social Development is to promote gender equality and women's empowerment through gender mainstreaming in the development process, capacity building, social protection, community participation and public - private partnerships. These strategies are informed by and consistent with the objectives of the flagship projects under the social pillar of the Kenya Vision 2030 .

According to Dacks (1990), devolution means the transfer of powers from the central order of government to a local order of government. In this case the governments devolve functions; they transfer powers for decision making, finance and management to independent units of local government with corporate status. Devolution transfers responsibility for services provision to counties that elect their own leaders. Devolution is seen as having cultural, economic and political dimension. To be successful, devolution demands political developments that will create capacity of the region to handle the transfer of powers. Political leaders play the role of articulating demands, as well as negotiating the transfer of powers with the higher order of government. In striving to achieve its fiscal and macro-economic policies of employment, equitable distribution of resources, economic growth and others; the Government of Kenya has established various devolved funds each addressing a specific objective. These funds include: Women Enterprise Fund, Youth enterprise fund, Poverty eradication fund, The Water Services Trust Fund, Road Maintenance Levy Fund, and Constituency HIV/AIDS fund. The key objectives of the devolved funds are to fund projects with immediate social and economic impact with a view to improving lives, alleviate poverty and general development purposes. Nakuru County is one of the 47 counties in kenya. According to census done in 2009, the county had a population of 814,180 (Republic of Kenya, 2009). Over 60 percent of this population is women. Thus the goal of development in the county must focus on women empowerment.

\subsection{Statement of the Problem}

Women are the majority in terms of population in many countries in the world. Despite this kind of scenario, gender equality has not been achieved and women are still lagging in terms of decision making processes especially in matters affecting their development. This has been due to under representation in decision making organs. Although women are the ones who turn out in large numbers during the elections, their 
substantive representation in elective positions remains poor. In Kenya the new constitution introduced major changes in the country's governance framework including a 30\% female gender representation in all elective and nominated positions (Constitution of Kenya (CoK), 2010). The objective of this requirement is to empower women so as to bring about equality in development. The devolution law requires that county governments should involve local women under their jurisdiction so that they can develop relevant programs which may empower women. Although this requirement is gradually being implemented, the goal of women empowerment still remains unrealized two years after the law came into force. Moreover, studies have not been conducted to ascertain the extent to which devolution has influenced women empowerment at the county levels in Kenya. Therefore, this study sought to address the existing research gap by assessing the impact of devolution on women empowerment in Nakuru County.

\section{METHODOLOGY}

The study adopted a descriptive survey design. The target population was made up of the elected and nominated members of the county assembly of Nakuru and registered women groups in Nakuru County. The study employed purposive samping to select a sample of 73 members of the county assembly while stratified random sampling was used to select 60 women group representatives. Data was collected using questionnaires. The questionnaires were piloted to ensure validity and reliability of the instrument.

\section{LITERATURE REVIEW}

\subsection{The Concept of Women Empowerment}

Women empowerment is the most important enabler of other empowerments. It gives women a voice, broaden their choices and dignity to claim their space in the society (Women Empowerment Forum, 2011).Empowering women economically is important for them to gain in terms of women rights and to achieve wider development goals like economic growth, poverty reduction, health, education and welfare(Golla, 2011). According to Wiego (2010), for women to achieve full empowerment there must be an integrated understanding of where women are in the economy, and what the consequences of gender differences are.He argues that empowering women economically does not only benefit them alone but also society as a whole.He further says that it promotes women's ability to achieve their rights and well-being while also reducing household poverty, increasing economic growth and productivity, and increasing efficiency. There are strong reasons to emphasize women empowerment since it is the one of the most powerful routes for women to achieve their potential and advance their rights since women make up the majority of the world's poor (Chen \& Mahmud, 1995). Meeting poverty-reduction goals requires addressing women and their economic empowerment. Discrimination against women is economically inefficient. Women can achieve economic empowerment if the resources are available and women have the skills to utilize them, they have access to economic opportunities and control over the benefits of those opportunities, and they can use those benefits to make strategic choices leading to positive changes in their lives (Booz \& Co., 2012). Furthermore, Booz (2012) argues that income interventions for women can help to change traditional gender norms that influence family spending on female children. Rising aspirations for girls, along with increased family spending on them, may be among the most consequential benefits of women empowerment. Lakshman (1996) argues that women empowerment has brought positive changes in household and community perceptions of womens' productive role, as well as changes at the individual level. In societies like Sudan and Bangladesh where womens' role has been very circumscribed and women previously had little opportunity to meet women outside their immediate family there have sometimes been significant changes. Women's limited access to productive resources and inputs stems from market and institutional failures, such as having less access to up-to- date information about markets and prices than men because of time or social constraints (Kabeer, 2012).

Globally many more women than men are unemployed; women unemployment rate is higher than those of men in 113 out of 152 countries for which there is available data (ILO, 2010). The World Bank Report (2011) on women empowerment explains that many countries in the world have statutory laws which explicitly discriminate against women. Along with formalized gender discrimination, attitudes and behavior on the part of actors in the public arena can further curtail women's capacity to take advantage of economic opportunities. In both Mozambique and Tanzania, husbands and fathers prevent women from engaging in outside paid work, particularly forms of paid work where they were likely to come into contact with other men (Oya, 2010). In Mexico, women confirmed that husbands were openly against or at best dubious about having spouses work outside the home. According to (UNF, 2013), entrepreneurship is a significant source of women's economic opportunity employment and income generation for both urban and rural women, especially in agrarian and urbanizing economies where wage employment opportunities for women are scarce. In Kenya devolution is one of the important instruments for women empowerment. 


\subsection{Overview of Devolution}

According to Bennett (1990) devolution as a multi-dimensional approach organizes governance and manages state power in many lines.He argues that devolution defines, distributes and constrains the governments' power along multiple lines by combining both vertical and horizontal dimensions. He further says, devolution forms the foundation for federal systems and structures of government and is founded upon the concept of decentralization and devolution of power.

According to Bogdanor (2001), devolution has profound implications for the way in which people are governed and for the kind of society in which they live in. Cultures and values form the backbone of political devolution According to Deacon (2012), devolution is not simply the description of another political process but a major and a fundamental shift in the political structure of any country and the engine by which the constitution is completely reformed (Pilkington, 2002). Devolution does not necessarily stop at the level of the city and regional governments but may extend to networking arrangements with many other partners which may not be controlled by regional or national levels (OECD, 2001). Most individuals and governments favour the concept of decentralization as it implies the hope of cracking open the blockages of an inert central bureaucracy and curing managerial constipation. According to Mahwood (1993) devolution gives a more direct access for the people to the government and the government to the people thus stimulating the whole nation to participate in national development plans.

The empowerment framework is anchorerd on the capacity of an individual or group to make effective choices and is primarily influenced by two sets of inter-related factors (Alsop \& Heinsohn, 2005). These factors are agency and opportunity structure. Agency is one's ability to make meaningful choices whereas opportunity structure is the formal and informal institutional context in which actors operate and it determines the actor's ability to transform agency into effective action outcomes (Alsop \& Heinsohn, 2005). According to Pilkington (2002) devolution can be seen as the process by which political power is transferred from the center to local or regional bodies which thereby carry out government functions while leaving sovereign in the hands of the central government. According to Mishra, Mishra, and Mishra (2003) one of the four fundamentals of decentralization is empowerment of women. Women's levels can be seen in terms of four levels. These are welfare, access, conscientization and control.

According to Mishra (2003) women power means having control, organizing further control, having a say and being listened to, being able to define and create from a woman's perspective and being able to influence social choices and decisions affecting the whole society not just areas of society accepted as women's place. But also being organized and respected as equal citizens and human being with a contribution to make.

\subsection{Theoretical Framework}

This study was guided by the allocative efficient theory( Motta,2004). The theory argues that the most common aspect of decentralization is that it improves the efficiency of resource allocation. Decentralized levels of government have a role to play in providing goods and services to the areas of their operations. By designing goods and services that satisfies the needs of the people they serve, decentralized governments increases economic welfare above what the national government can be able to provide since they are well aware of the needs of the people in their jursdictions. The basic point here is simply that the efficient level of output of a "local" public good likely to vary across jurisdictions as a result of both differences in preferences and cost differentials (Oates, 1999) as cited in Mueni (2014).

One pillar of Devolution is that because sub-national governments are closer to the people than the central government, they are considered to have better information about the preferences of local populations than the central government (Hayek, 1945; Musgrave, 1959). Hence, they are argued to be better informed to respond to the variations in demands for goods and services. Second, sub-national governments are also considered to be most responsive to the variations in demands for and cost of providing public goods. Decentralization is thought to increase the likelihood that governments respond to the demand of the local population by promoting competition among sub-national governments (Tiebout, 1956).

Competition among sub-national governments is said to allow for a variety of bundles of local public goods to be produced, and individuals are said to reveal their preferences for those goods by moving to those jurisdictions that satisfy their tastes--that is, by "voting with their feet." This is seen to pressure sub-national governments to pay attention to the preferences of their constituents and tailor the service delivery accordingly, whilst risking the loss of tax revenues (Breton, 1996). This "voting with feet" is thus argued to enhance the efficiency of resource allocation by increasing the likelihood that governments satisfy the wishes of citizens. Where geographic mobility is constrained, as in many developing and transition countries, alternative service providers such as private firms and NGOs are potentially important in providing exit options (Qian \& Weingast, 1997). Devolved functions improve the efficiency of resource allocation to projects that will empower more women within a County. For example, tailoring outputs of such goods and services to the particular preferences and circumstances of women, decentralized provision should increase economic welfare of women above that 
which results from the national provision. Units of County government should to respond to the variations in demands for goods and services for women who reside within the same area.

\subsection{Conceptual Framework}

The interrelationship between the study variables is diagrammatically shown in Figure 1. In the figure, substantive women representation, development of programs and accessibility of public services were the independent variables while women empowerment was the dependent variable.

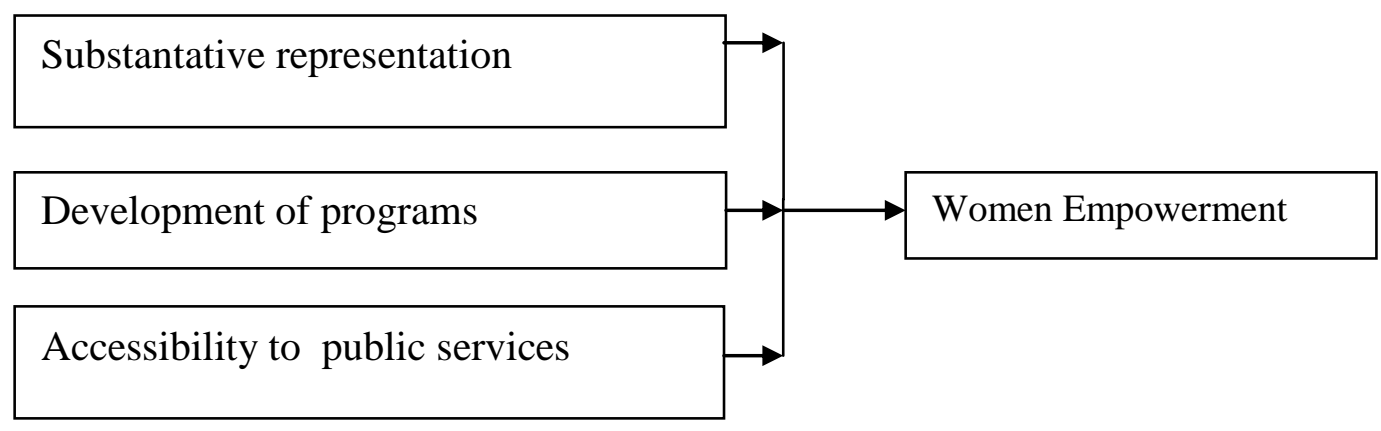

Independent Variables

Dependent Variable

Figure 1: Conceptual Framework

\subsubsection{Devolution and Women Substantive Representation}

The main framework for women substantive representation is based on UNESCO's (2009) gender mainstreaming approach which aims to ensure that women and men benefit equally from participation in political processes. Mainstreaming consists of bringing what can be seen as marginal into the core and main decision making process of an organization (UNESCO, 2003) as cited in Awuor (2013). Kabeer (1999) conceptualizes empowerment through choice making in terms of resources, agency and achievements, while Unterhalter (2011) identifies four facets of empowerment namely cognitive, sociological, political and economic. Education is critical because it promotes gender equality and empowers women, and it is the key to addressing gender-based inequalities and exclusion. (UNESCO, 2011) points out that women's needs and interests have been marginalized in the development of political policy. It is necessary that clear institutional strategies are put in place to realize gender equality in political parties' participation. This is made even urgent given the provisions of the Constitution on gender equity and the Political Parties Act 2011 on gender representation. The UN describes gender mainstreaming as a way of making the concerns and experiences of women as well as men an integral part of the design, implementation, monitoring and evaluation of policies and programmes in all political, economic and societal spheres so that women and men benefit equally and inequality is not propagated. United Nations (1997) as quoted in Unterhalter \& North (2010), states that empowerment is viewed from the standpoint of Kabeer (1999) who holds that it is a process by which those who have been denied the ability to make choice acquire such ability. It is thus a choice from disempowerment to empowerment and an expansion in the people's ability to make strategic life choices.

According to Sivi-Njonjo (2010), a recent study on participation of women in decision-making in Kenya concluded that age and employment status does influence the level of decision-making by the women. It also indicated that those who have no education at all make relatively few household decisions at home as compared to those with secondary education and above. A critical assumption is that participation in decision making at home is a measure of a woman's autonomy and status.

Accordng to a study by Omondi (2010) women have a very active role in the private sphere, with about $78 \%$ of women deciding about how to spend money in the home in terms of daily purchases of household needs. women have been excluded from the public arena, with women only given "housekeeping duties" in the House Committees of the National and County Assemblies. The study also found that older women and women in employment were more likely to be involved in decision-making, a finding that we might expect to be repeated in political decision-making. Employment anticipated here is critical as it is a function of education. $83.9 \%$ of the women-aged between 30 - 34 years old make decisions daily in the purchase of household needs. Omondi (2010) appreciates the fact that institutions of higher learning have acted as "nursery beds" for national leadership development. Mitullah and Owiti (2007) observe that since the beginning of transition politics in 1992 there is womens increased participation in national politics.However, they're still disadvantaged in political participation and decision-making because their numbers are comparatively lower than those of men. Barriers to equal representation in decision-making bodies remain widespread despite better education and training 
meaning that more gender equality in terms of participation in education has not resulted in more gender equality in other areas of political economy or socio-cultural relationships. (Unterhalter, North \& Parkes, 2010) and Oduol (2011) decries the lack of institutional structures at the party level to enhance women participation, "which essentially projects not only their helplessness, but also their lack of key leadership qualities." (Oduol, 2011). The Beijing Platform for Action affirmed that "equality of access to and attainment of educational qualifications is necessary if more women are to become agents of change (Unterhalter, 2010).

According to Republic of Kenya (RoK) (2011), every political party shall respect and promote gender equity and equality, human rights and fundamental freedoms and be tolerant and inclusive in all their political activities. Every political party shall respect, uphold and promote human dignity, equity, social justice, inclusiveness and non-discrimination and protection of the marginalized. It is based on these provisions of the Political Parties Act 2011 that this paper seeks to establish the levels of compliance and the mechanisms that have been put in place for compliance. A study conducted in 2008, established that in most political parties, the increase of women presence in the keydecision-making organs has not resulted into key influence within the party hierarchy that has been seen to impact on party affairs and activities (WSP, 2008).

Among the factors that hinder the participation of women in political processes is their limited participation in political parties and the lack of political goodwill by their male counterparts to include them in structures of political governance in the various public institutions or organizations (Oduol, 2011). The marginalization of women in the political arena is evident since and has witnessed limited presence of women in parliament, within political parties and in other institutions or organizations (WSP, 2008). However, some scholars feel that if the concern is to bring gender equality perspectives into politics and public policy, a focus on packing public space with female bodies is misplaced unless supported by efforts to bring gender issues into the many other spaces where political interests are formed (Cornwall \& Goetz, 2005).

Kang'ethe (2007) has observed that even though affirmative action is highly rated as the way forward, it should be viewed as only one of the instruments for achieving equity and justice. Admitted that women must learn to exploit their numerical strength in occupying political space, there is need to consider the quota system which has yielded much success in countries like Rwanda (Powley 2004; Huggins \& Randell 2007) and Uganda (Cornwall \& Goetz, 2005). One indicator of gender inequality in Kenya is the small number of women in decision making positions and other national governance structures. The $10^{\text {th }}$ Parliament has about $10 \%$ of women representation which is far below the Constitutional threshold of 30\% (Awuor, 2013).

The new Constitution is a gender responsive document that has led to the following gains for the women, among others: that all forms of discrimination including discrimination against women are expressly outlawed.Women representation is guaranteed; and there is an increased number of women in all decisionmaking organs including in the devolved government. The number of nominated women for Parliamentary positions has been steadily rising with the highest number being 8 in 2002, although it went down to 6 in 2007 , possibly attributable to the high number of elected women to Parliament (Awuor, 2013). Awuor (2013) points out that with the affirmative action provisions of the new Constitution, the nominations at the political party level has to ensure that women have to be not less than one-third of the MPs. Even when women are in parliament, they are given "housekeeping jobs" like catering, library and House business, and hardly any are involved in the key departmental committees. Women are missing in the Standing Orders Committee and given that this contains the rules that guide the procedures of the House, this is an important omission as women end up playing no role in designing and amending the rules of the House (WSP 2008). There is a high level of women participation in political party activities at the local levels.

The political parties have seen the need for complying with the legal provisions on gender equity in party responsibilities. This is reflected in the fact that over $85 \%$ of the political parties have at least $30 \%$ female officials. However, only those which attain the minimum threshold will be registered. By the time of collecting this data, as Awuor (2013) states, the parties were still struggling to comply with the provisions for full registration. Constitution of Kenya is a gender responsive document that has led to the outlawing of all forms of discrimination including discrimination against women, guaranteeing women representation and increasing the number of women in all decision-making organs including in the devolved units of government. If effectively implemented, this Constitution will greatly improve on the participation of women in political party processes.

According to Rowlands (1997) women should be given the chance to occupy positions of power in terms of political and economic decision-making. He argues that empowerment is concerned with the processes by which people became aware of their interests and how they relate to the interests of others, in order to participate from a position of greater understanding in decision-making and influence such decisions. He argues that empowerment must involve undoing negative social constructions, so that people come to see themselves as having the capacity and the right to act and influence decisions. Gender equality in leadershipensures recognition of both women's and men's needs and also better rewards and more equitable allocation of public monetary resources(Grown, Rao Gupta \& Khan, 2005). They argues that it will give better results and more 
equal allocation of public resources and delivery of social amenities such as ,education, water, and health services.

According to Sahay (1998), systems must recognize that women's problems stem from inherent structures and institutions that discriminate them. He argues that, traditional governance institutions in most developing countries plays an important role at the community level and can be used to address women's problems.Positions of power are male dominated in these institutions and their structures such as village development committees, religious circles, village council of elders, and even in local politics.Grass roots gender campaignsare playing an important in changing these in some parts of the world. In china, the number of women elected as village heads increased three folds between 2003 and 2009 (Xiaoxian, 2010).

The legal status and approach of decentralization programs and policies of African countries since independence have been stipulated in one or two ways (Hope, 2011). The latter author states that one of ways is by the enactment of lower-level laws or use of administrative regulations and secondly is the use of a constitution. Kenya opted for the use of the constitution and in 2010 the new constitution was promulgated which had the support of more than two thirds majority in the referendum (Dagne, 2011). Decentralization and local governance got a boost from the new constitution.

\subsubsection{Barriers of Meaningful Substantive Representation}

The way the society view's women and the general perception of their place in the public arena are wide spread and acts as an obstacle for women who want public participation or even community influence(Akapire, Awal \& Fuseini, 2011).They argue that this makes even harder for women who engage in politics to be accepted by their female voters within their constituents. Goetz (2004) points out that cultural and religious biasness against women taking on leadership roles is also a formidable obstacle. He argues that in addition to taking affirmative action's; there is a need to overcome the rigid social and cultural barriers, which hinders women's participation in the public sphere.infact in some countries it has been reported by women candidates that their political parties often remove them from nomination lists andget replaced by their male competitors who are considered to likely win the elections (Hoare \& Gell, 2009).

Women also fear taking leadership roles because of their acceptance of the gendered division of labour and this means that the already substantial burden in the home where women have no influence may lack time and money as a deciding factor (Urgel \& Tanyang, 2009). Womens domestic and publis roles remains a challenge when elected to government office and this strain of trying to balance public life with their public participation affects their career progression and some ends up resigning from their public positions (OfeiAboagye, 2000).Also,lack of control in making decision on when or not to have children makes it difficult for women to plan their participation in leadership contests or elections or to develop into leadership positions within their economic sector (Hoare \& Gell, 2009). They argue that this explains why it is important to have important reproductive rights to enable women participate and take leadership positions. Inaddition, women's health and educational prospects plays an important part in their capacity and courage to have them go for the roles in political and public life.

In the developing world where women face challenges to participate in public arena reserved seats, quotas and international agreements are all working towards slow stimulation but necessary change to the numbers of women participating in political and public arena. According to the United Nations, 22 countries out 48 that held their elections 2012, the use ofreserved seats, quotas and other legislationswere responsible in increased women representation in their national parliaments. $24 \%$ of parliamentary seats were taken up by women in countries where quotas have been legislated and $22 \%$ of the seats through voluntary quotas.In countries where there are no women took up only $12 \%$ of the seats which is quite below the global average (United Nations, 2013).

\subsubsection{Devolved Programs and Women Empowerment}

According to Crone (2010), a lot of research shows that organizations that fight for women's rights and women programs have important role not just in mobilizing women to be candidates and participate in voting, but again they help them develop networks, supportive relationships, skills, knowledge and confidence which are important to make them exercise political agency at a personal level.He argues these networks provides support systems that women need to help them develop interms of increased numbers and also decrease advocacy activities that arouse a feeling of marginalization and isolation.

Caiazza(2006) advocates that effective mentoring programmes in politics which will involve the provision of frequent conversations and advice provide an opportunity to challenge women to take on greater responsibilities, become more active in political arena and make decisions on political strategies to employwomen should be fully aware that they cannot make it alone as they fight for equality. They should map out their strategies on how to involve men champions in positions of power who will advocate in support of their rights to get to political leadership and participation.Such champions are important creating in changing 
men's attitudes and also encourage men who support gender equality to speak out (Hoare and Gell, 2009).In order to make women aware of their exclusion, active citizen is needed where supporting women's groups and NGOs will create space for interaction between citizens and institutions (Meer and Server, 2004). According to Sahay (1998), the empowerment of women by their increased participation in all aspects of political, social and economic life has become one of the major goals of democratic and participatory movements including women organizations throughout the world.

When women are unable to create policies or change policies and behaviours that are against their progress ,they become more vulnerable (Horner \& Stokes, 2012).they argues that at that point they are fruatrated when those in power and hold influence fail to give them an ear on how to change things and make them better. Decentralization shifts power to citizens and local governments elected and administrative thereby enhancing their capacities to make effective choices to translate their choices into desired actions and outcomes. According to Sahay (1998), control is the ultimate level of equality and empowerment.In this women are able to make decisions over their lives and the lives of their children, and play an active role in the development process.

\subsubsection{Accessibility of Services for Women Empowerment}

To enhance women's descriptive representation both in local and national politics it is very vital to decentralize government institutions and operations (Khan, 2001).He argues that women can influence the formulation of policies that affects women and give them access to different services they get a fair representation in decision making structures.Substantive representation is normally affected by descriptive representation and can have profound impacts on issues that woman in general (ROK, 2011). This means that they will be able to address and safeguard women's interests. Khan argues that for women to have substantive representation it is important for them to have descriptive representation as well. Gilligan (1982) agrees that women all over the world have common issues that affect them. Their common experiences as women may mean they have a different voice and hence cannot be represented by men wholly (Gilligan, 1982).

It has been discovered that women representation has profound results on women life's since they prioritize legislation on families, children, health care and women's rights (Carroll, 1995).According to Bratton(2002) elected women can therefore act a symbolic role both for women and men since they can greatly inspire other women. Women should ensure that they participate in politics out of their own capacities and will power. According to Hust (2002) there are no guarantees that women representative will work for the benefit of other women because most of the times women get into politics due to personal connections or support form elites.This makes them to always want to please those who appointed them and cannot therefore be able to willingly support grassroots women's interests for fear of falling out of their counterparts (Hust, 2002).

Politics itself is about power (ROK, 2011).He argues that it involves power over who should get what, how and when, and the power over values, ideas and recourses.It also means power to take decisions, power to influence decisions.All in all this leads to a fact that political presence can greatly help empower women.Political presence of women in decision-making structures and its impacts on the formulation of policies can succeed if structures undergoes democratic decentralized to support the above argument are being tested using democratic decentralization as a policy approach (ROK, 2011). ROK argues that descriptive representation effect on substantive representation of women can greatly bear fruits in empowering women.ROK concludes that the higher the number of women in the decision-making structures, the greater the chances to safeguard women's interest andto influence formulation of policies that affect women in totality.

Though actively involved in the nationalist struggle for independence, Kenya's women were sidelined during negotiations for independence early and post-colonial politics (Murunga \& Nasong'o, 2007). They argue that only one woman was present out of about seventy or so Kenya delegates at the Lancaster House conference in London, where Kenya's independence constitution was negotiated. According to Lumumba \& Kiwinda (2014) the constitution provides a tremendous opportunity for mainstreaming women into the wider Kenya community. They argue that the constitution attacks both public and private acts and decisions that have been used to exclude women from important aspects of life. The constitution also allows for specific interventions such as affirmative action's and numerical quotas in public institutions thus recognizing the insufficiency bare formal equality (Lumumba \& Kiwinda, 2014).According to Lumumba and Kiwinda (2014b), by merely providing for equality is not sufficient. As Thomas Jefferson said" there is nothing more unequal than the equal treatment of unequal people. For this reason, the constitution in section 27(b) imposes an obligation on the state to "take legislative and other measures, including affirmative action programmes and policies designed to redress any disadvantage suffered by individuals or groups because of past discrimination". Article 27(8) provides a numerical benchmark according to Lumumba \& Kiwinda (2014), in that the state shall take legislative and other measures to implement the principle that not more than two thirds of members of elective or appointed bodies shall be of the same gender.

According the constitution, the state is therefore under an obligation to ensure that historically marginalized groups like women will justly be free to participate in mainstream society including political 
leadership (Lumumba \& Kiwinda, 2014). They argue that certain positions will be reserved for them so that they do not have to suffer the rigours of unequal political competition. Further, to "ensure greater certainty (Lumumba \& Kiwinda, 2014). As far as the obligation of the state is concerned part 3 of chapter four provides for the "specific application of rights "of certain of the rights in the bill of rights to certain groups of persons. Section 56 is expressed to "minorities and marginalized groups.

According to Lumumba \& Kiwinda (2014) the constitution offers no definition for "minorities" but defines "marginalized groups" to mean a group of people who because of laws or practices ,or after the effective date, were or are disadvantaged by discrimination or one or more of the groups in article 274. Since women have traditionally been discriminated by the "laws and practices" the affirmative action programmes defined by the section should equally apply to them (Lumumba \& Kiwinda, 2014).

In order for one to use the word "representation" one must be conscious that one is doing so (Peterson, 1996). According to Judge and Judge (2005), political representation is primarily a public, institutionalized arrangement involving many people and groups which operates in the complex ways of large scale social arrangements. Political representation, as Pitkin (1967) points out, should be conceived, and analyzed in terms of the overall structure of the political system itself. She argues that the government requires machinery for the expression of the wishes of the represented, and that it should respond to the wishes unless there are good reasons to the contrary. Chapter Seven of the Constitution sets out the principles of the electoral system. These principles are aimed at guiding the electoral sphere and representation of diverse groups in the society. Amongst identified principles are; freedom of citizen to exercise their political rights under Article 38, not more than twothirds of the members of elective public bodies shall be of the same gender, fair representation of persons with disabilities, universal suffrage based on the aspiration for fair representation and equality of the vote and free and fair elections. Article 90 introduces the concept of proportional representation in the allocation of additional seats under the constitution. The additional seats are to be allocated in the Senate, National Assembly and important for women's purposes County Assemblies.

\subsection{Summary and Research Gap}

This section presents the summary of the literature review in relation to the variables of the study. That is, relevant literature has been reviewed on the impact of devolution on women empowerment in Nakuru County. The variety of possibilities of different methods, kinds, contents, goals, and ways of distribution of powers is almost unlimited. This opens a big range of flexibility and creativity for any state which has decided for devolution of its central powers and jurisdiction. The available literature on the impact of devolution on women empowerment is too general in nature. The study at the same time, the available literature is parochial in scope and mostly published by government. Thus, the study addressed these precincts through the findings. The study addressed the following objectives of the study: To determine if devolution has enlarged women's substantive representation in Nakuru County; to determine if devolution has enabled development of programs to empower women in Nakuru County; and to establish how accessibility of services through devolution affects women empowerment. From the existing literatures, there was gap between stated policies and real practices that guide devolution matters. These are causing women leaders to exhibit frustrations because application of existing recognized models at the global level may not be imported because of their alien nature. From the various studies undertaken globally on devolution, in different platforms, there is very little, if any, evidence relating to its impact on women empowerment in Nakuru County. While some investigations have been initiated in different countries, the available literature highlights that most of the studies examining the relationship between government policy development and women empowerment have been conducted for both civil servants and women empowernment, mostly in the developed countries. None of these studies have been done in any developing countries, especially those that have devolved structure of governance like Kenya. From the previous studies done on the area of devolved governance and women empowernment, the researcher did not find any literature or study done in relation to an assessment of the impact of devolution on women empowerment in Nakuru County. Therefore, this is the driving force that made the researcher to concentrate on Nakuru County.

\subsubsection{Women Substantive Representation.}

\section{FINDINGS}

This section presents the results on the first objective of the study which sought to find out the influence of substantive representation on women empowerment in Nakuru County. The researcher sought to establish whether there was substantive women representation in Nakuru County. The results are presented in the Table 1.

Table 1: Whether there was Substantive Women Representation

\begin{tabular}{|l|c|c|}
\hline Response & Frequency & Percentage (\%) \\
\hline
\end{tabular}


An assessment of the Impact of Devoluton on Women Empowerment in Nakuru County

\begin{tabular}{|l|c|c|}
\hline Yes & 51 & 39 \\
\hline No & 79 & 61 \\
\hline Total & $\mathbf{1 3 0}$ & $\mathbf{1 0 0}$ \\
\hline
\end{tabular}

The findings show that slightly less than half of the respondents (39\%) believed that there was substantive Women Representation in Nakuru County. However, majority of the respondents (61\%) disagreed. Based on a higher percentage of the respondents expressing disagreement that there was substantive women representation, more needed to be done in enhancing women empowerment through substantive representation in the County

\section{Effect of Women Substantive Representation}

This section presents the descriptive analysis of results of the study on substantive representation of Women in Nakuru County. The results were analyzed using mean and standard deviations of the responses. They are discussed further under the various indicators of women substantive representation as presented in Table 2.

Table 2: Substantive Representation of Women

\begin{tabular}{|l|l|l|l|l|l|}
\hline Indicators & $\mathbf{N}$ & $\mathbf{M i n}$. & $\mathbf{M a x}$. & $\begin{array}{l}\text { Mea } \\
\mathbf{n}\end{array}$ & $\mathbf{S D}$ \\
\hline $\begin{array}{l}\text { Devolution has enlarged women's substantive } \\
\text { representation in Nakuru County }\end{array}$ & $\mathbf{1 3 0}$ & $\mathbf{1}$ & $\mathbf{5}$ & $\mathbf{3 . 4 2}$ & $\mathbf{0 . 3 2}$ \\
\hline $\begin{array}{l}\text { Elected and nominated women leaders are carrying out } \\
\text { their manadate as reqiured by law }\end{array}$ & $\mathbf{1 3 0}$ & $\mathbf{1}$ & $\mathbf{5}$ & $\mathbf{2 . 5 0}$ & $\mathbf{0 . 2 6}$ \\
\hline $\begin{array}{l}\text { Women's participation in political life has received } \\
\text { support and commitment from men }\end{array}$ & $\mathbf{1 3 0}$ & $\mathbf{1}$ & $\mathbf{5}$ & $\mathbf{3 . 4 7}$ & $\mathbf{0 . 8 3}$ \\
\hline $\begin{array}{l}\text { There is increase of women presence in key decision- } \\
\text { making organs in Nakuru County }\end{array}$ & $\mathbf{1 3 0}$ & $\mathbf{1}$ & $\mathbf{5}$ & $\mathbf{3 . 2 1}$ & $\mathbf{0 . 3 9}$ \\
\hline $\begin{array}{l}\text { Women have exploited their numerical strengths in } \\
\text { occupying political space }\end{array}$ & $\mathbf{1 3 0}$ & $\mathbf{1}$ & $\mathbf{5}$ & $\mathbf{3 . 8 5}$ & $\mathbf{0 . 7 3}$ \\
\hline $\begin{array}{l}\text { Women have control and say in influencing social } \\
\text { choices and decisions affecting the whole society }\end{array}$ & $\mathbf{1 3 0}$ & $\mathbf{1}$ & $\mathbf{5}$ & $\mathbf{3 . 7 5}$ & $\mathbf{0 . 6 6}$ \\
\hline $\begin{array}{l}\text { Increase of women presence in key decision-making } \\
\text { organs has resulted into key influence within the party } \\
\text { hierarchy }\end{array}$ & $\mathbf{1 3 0}$ & $\mathbf{1}$ & $\mathbf{5}$ & $\mathbf{2 . 9 7}$ & $\mathbf{0 . 7 8}$ \\
\hline
\end{tabular}

The results as indicated in Table 2 suggest that the respondents agreed that devolution had enlarged women's substantive representation in Nakuru County as reflected by a mean response of 3.42. However, a significant standard deviation of 0.32 indicated that there were variations in responses concerning whether devolution had actually enlarged women's substantive representation in Nakuru County. Results regarding whether elected and nominated women leaders were carrying out their manadate as required by law shows that the respondents were indifferent as shown by a mean value of 2.50 with a standard deviation of 0.26 which showed minimal variation in the responses in regard to this indicator. It is also revealed that the respondents agreed that women's participation in political life had received support and commitment from men as indicated by a mean value of 3.47. However, the corresponding standard deviation of 0.83 shows that there was relatively high variation in responses from the respondents in regard to this indicator.

Concerning whether there was an increase of women presence in key decision-making organs in Nakuru County, the results shows an agreement as reflected by a mean value of 3.21 while the corresponding standard deviation of 0.39 shows that there were also slight variations in the responses as far as this indicator was concerned. The respondents also agreed that women had exploited their numerical strengths in occupying political space as shown by a mean value of 3.85. Nevertheless, a standard deviation of 0.73 suggested that the variation was high in the responses as far as this indicator was concerned.

In regard to whether women have control and say on matters influencing social choices and decisions affecting the whole society, the respondents agreed as revealed by a mean of 3.75 with a standard deviation of 0.66 which also suggested slight variation in responses as far as this test was concerned. The findings also show that the respondents slightly disagreed that increase of women presence in key decision-making organs has resulted into key influence within the party hierarchy as indicated by a mean value of 2.97 although it shows that the standard deviation of 0.78 shows that the respondents varied greatly as far as this test was concerned. 


\subsubsection{Descriptive Statistics on Women Empowerment Programs}

The second objective of the study sought to examine the role of development of programs on women empowerment in Nakuru County. The indicators of development of programs of Women Representatives were analyzed in terms of their mean and standard deviation and the findings presented in Table 3.

Table 3: Indicators of Development of Programs

\begin{tabular}{|c|c|c|c|c|c|}
\hline Development of Programs & $\mathbf{N}$ & $\begin{array}{c}\mathrm{Mi} \\
\mathrm{n}\end{array}$ & $\begin{array}{l}\mathrm{Ma} \\
\mathrm{x}\end{array}$ & $\begin{array}{c}\text { Mea } \\
\mathrm{n}\end{array}$ & $\mathrm{SD}$ \\
\hline $\begin{array}{l}\text { Women's organizations have strengthened women's } \\
\text { capacity to influence development oriented programmes }\end{array}$ & $\begin{array}{l}13 \\
0\end{array}$ & 1 & 5 & 4.00 & 0.60 \\
\hline $\begin{array}{l}\text { There are programmes addressing issues relating to } \\
\text { gender-based inequalities and exclusion }\end{array}$ & $\begin{array}{l}13 \\
0\end{array}$ & 1 & 5 & 2.25 & 0.92 \\
\hline $\begin{array}{l}\text { Institutional structures enhance women participation in } \\
\text { projects }\end{array}$ & $\begin{array}{l}13 \\
0\end{array}$ & 1 & 5 & 3.59 & 0.76 \\
\hline $\begin{array}{l}\text { There are institutional structures at the county level to } \\
\text { enhance women participation developem programmes }\end{array}$ & $\begin{array}{l}13 \\
0\end{array}$ & 1 & 5 & 3.13 & 0.34 \\
\hline $\begin{array}{l}\text { Institutions created through devolution promotes gender } \\
\text { equity and equality }\end{array}$ & $\begin{array}{l}13 \\
0\end{array}$ & 1 & 5 & 2.92 & 0.85 \\
\hline $\begin{array}{l}\text { There are programmes designed to enhance women } \\
\text { inclusiveness in all political activities in Nakuru County }\end{array}$ & $\begin{array}{l}13 \\
0\end{array}$ & 1 & 5 & 3.81 & 0.89 \\
\hline $\begin{array}{l}\text { There are programes designed to equip women with } \\
\text { special responsibility to represent the needs and interests } \\
\text { of women }\end{array}$ & $\begin{array}{l}13 \\
0\end{array}$ & 1 & 5 & 3.34 & 0.82 \\
\hline
\end{tabular}

As shown in Table 3 majority of the respondents were in agreement that women's organizations have strengthened women's capacity to influence development oriented programmes as reflected by a mean value of 4.0. However, a standard deviation of 0.6 suggested slight variation in responses in regard to the same test. Moreover, the findings pertaining to whether there were programmes addressing issues relating to gender-based inequalities and exclusion shows a mean response rate of 2.25. However, a standard deviation of 0.92 suggested a relatively high variation in responses. The findings also show that the respondents disagreed that institutional structures enhanced women participation in projects. This is revealed by a mean of 3.59. However, a standard deviation of 0.76 suggests a significant variation in the responses generated from the respondents. Moreover, the findings show that the respondents slightly agreed that there were institutional structures at the county level to enhance women participation developemt programmes. This is revealed by a mean response rate of 3.13. However, the standard deviation of 0.34 suggests low variation in the responses generated. Results of the study in regard to whether institutions created through devolution promoted gender equity and equality revealed a mean value of 2.92 with a standard deviation of 0.85 which suggests that in as much as the respondents tend to disagree that institutions created through devolution promoted gender equity and equality, they varied greatly in their responses.

From the study, it can be deduced that respondents agreed that there were women programes designed to promote tolerance and inclusiveness in all political activities in Nakuru County. This is revealed by a mean value of 3.81, although the standard deviation of 0.89 revealed a relatively higher variation in responses generated. Moreover, majority of the respondents marginally agreed that there were programmes designed to equip women with special responsibility to represent the needs and interests of women as indicated by the mean value of 3.34. A significant standard deviation of 0.82 indicates varied responses from the respondents on the same, implying that they had different opinions on the same indicator.

\subsubsection{Accessibility of Services}

This section presents results on the influence of accessibility of services on the women empowerment in Nakuru County. The findings as presented in Table 4 are based on the extent to which the respondents agreed with different indicators of accessibility of services on Women empowerement. The statements have been arranged in terms of their means and standard deviations to bring out a meaning out of the results. The details of the findings are discussed in comparison with previous findings.

Table 4: Indicators of Influence of Accessibility of Services

\begin{tabular}{|l|c|c|c|c|c|}
\hline Indicators & $\mathbf{N}$ & Min & Max & $\begin{array}{c}\text { Mea } \\
\mathbf{n}\end{array}$ & SD \\
\hline There is enhanced accessibility by women to a tremendous & $\mathbf{1 3 0}$ & 1 & 5 & 4.08 & 0.38 \\
\hline
\end{tabular}




\begin{tabular}{|l|c|c|c|c|c|}
\hline $\begin{array}{l}\text { opportunity for mainstreaming them into the wider } \\
\text { community. }\end{array}$ & & & & \\
\hline $\begin{array}{l}\text { Accessibility of services promotes women empowerment in } \\
\text { Nakuru County }\end{array}$ & $\mathbf{1 3 0}$ & 1 & 5 & 3.70 & 0.98 \\
\hline $\begin{array}{l}\text { Opportunities for women to participate meaningfully in } \\
\text { public life are affected by access to education, healthcare and } \\
\text { decent livelihoods }\end{array}$ & $\mathbf{1 3 0}$ & 1 & 5 & 4.24 & 0.44 \\
\hline $\begin{array}{l}\text { There are no barriers to equal representation of both genders } \\
\text { in decision-making organs in Nakuru County }\end{array}$ & $\mathbf{1 3 0}$ & 1 & 5 & 2.48 & 1.00 \\
\hline $\begin{array}{l}\text { It is easy to access public office as a result of quotas and } \\
\text { constitutional requirement }\end{array}$ & $\mathbf{1 3 0}$ & 1 & 5 & 3.21 & 0.71 \\
\hline $\begin{array}{l}\text { Women's needs and interests are accessible through the } \\
\text { development of political policies }\end{array}$ & $\mathbf{1 3 0}$ & 1 & 5 & 3.90 & 0.93 \\
\hline $\begin{array}{l}\text { There are different departments handling women issues at } \\
\text { the County level }\end{array}$ & $\mathbf{1 3 0}$ & 1 & 5 & 3.11 & 0.84 \\
\hline
\end{tabular}

As shown in Table 4 majority of the respondents agreed that there was enhanced accessibility of women to a tremendous opportunity for mainstreaming them into the wider community as indicated by a mean value of 4.08. This shows that the respondents generally agreed that the devolution had ensured that women were adequately empowered in Nakuru County. In addition, the corresponding standard deviation of 0.38 shows that there was no much variation in the responses provided by the respondents. The respondents also agreed that accessibility of services promoted women empowerment as reflected by the mean value of 3.70. However, a significant standard deviation of 0.98 suggests high variation. Moreover, results presented in Table 4 , in regard to whether oopportunities for women to participate meaningfully in public life were affected by access to education, healthcare and decent livelihoods shows a mean of 4.24, implying that the respondents agreed with the statement. Thus, a standard deviation of 0.44 suggests no significant difference in responses regarding whether oopportunities for women to participate meaningfully in public life was affected by access to education, healthcare and decent livelihoods.

The results in respect to whether there were no barriers to equal representation of both genders in decision-making organs in Nakuru County showed a mean response of 2.48. This is slightly below the mean average, implying that the respondents slightly agreed that there were barriers to equal representation of both genders in decision-making organs in Nakuru County. In addition, a standard deviation of 1.00 reveals that the respondents had varied opinion in regard to this statement. The study results suggest that respondents agree that it was easy to access public office as a result of quotas and constitutional requirement is revealed by a mean score of 3.21 , although the standard deviation of 0.71 provided by the same respondents suggests that they showed significant variation in their responses. This could imply that the respondents were not conversant with the rights of women in relation to access constitutional requirement for access to public office by women. The findings also show that women's needs and interests were accessible through the development of political policies as showed by a mean response of 3.9. Nevertheless, the corresponding standard deviation of 0.93 suggests that respondents had a significant variation in their responses in regard to whether development of political policies ensured that women's needs and interests were easily met.

The analysis of results in Table 4.7 reveals that to some extent, there were different departments handling women issues at the County level as reflected by a mean value of 3.11. However, the respondents showed variation in their responses as revealed by a standard deviation of 0.84 .

\subsubsection{Women Empowerment}

This section presents the results on the women empowerment in Nakuru County. Wmen empowerment was examined by analyzing data collected under different dimensions of and computing for the mean and standard deviation of the responses obtained as presented in Table 5.

Table 5: Descriptive Statistics on the Indicators of Women Empowerment

\begin{tabular}{|l|c|c|c|c|c|}
\hline Indicators & $\mathbf{N}$ & $\mathbf{M i n}$ & $\mathbf{M a x}$ & $\begin{array}{c}\text { Mea } \\
\mathbf{n}\end{array}$ & SD \\
\hline $\begin{array}{l}\text { There is empowerment of women through increased } \\
\text { participation in political, social and economic life }\end{array}$ & $\mathbf{1 3 0}$ & 1 & 5 & 3.97 & 0.23 \\
\hline $\begin{array}{l}\text { There is public participation on matters relating to } \\
\text { empowerment of women of Nakuru County }\end{array}$ & $\mathbf{1 3 0}$ & 1 & 5 & 2.71 & 0.06 \\
\hline There is an increase in women participation in politics & $\mathbf{1 3 0}$ & 1 & 5 & 4.24 & 0.046 \\
\hline
\end{tabular}




\begin{tabular}{|l|c|c|c|c|c|}
\hline within Nakuru County & & & & & \\
\hline $\begin{array}{l}\text { Devolution ensures that women manage development } \\
\text { programs for women empower women in Nakuru } \\
\text { County }\end{array}$ & $\mathbf{1 3 0}$ & 1 & 5 & 2.78 & 0.84 \\
\hline $\begin{array}{l}\text { There is tolerance and inclusiveness in all political } \\
\text { activities in Nakuru County }\end{array}$ & $\mathbf{1 3 0}$ & 1 & 5 & 3.21 & 1.05 \\
\hline $\begin{array}{l}\text { Women have a special responsibility to represent the } \\
\text { needs and interests of women }\end{array}$ & $\mathbf{1 3 0}$ & 1 & 5 & 1.97 & 0.89 \\
\hline $\begin{array}{l}\text { Family obligations make it difficult for women to } \\
\text { plan their participation in leadership and economic } \\
\text { activities }\end{array}$ & $\mathbf{1 3 0}$ & 1 & 5 & 3.11 & 1.04 \\
\hline
\end{tabular}

As shown in Table 5, the respondents agreed that there was empowerment of women through increased participation in political, social and economic life as revealed by a mean value of 3.97 with a standard deviation of 0.23 . Low standard deviation suggests that there was minimal variation from the responses. It is also evident that there was public participation on matters relating to empowerment of women of Nakuru County. This is shown by a mean value of 2.71 with a low standard deviation of 0.06 revealing that there was no variation in the responses. However, low mean response rate could indicate that public participation was not adequate to enhance women empowerment in Nakuru County. The findings in regard to whether there was increase in women participation in politics within Nakuru County revealed a mean value of 4.24 with a standard deviation of 0.046 suggesting a homogeneity of responses in regard to this test.

It is also evident that the respondents were indifferent as to whether devolution ensured that women managed development programs for women empowerment in Nakuru County. This is revealed by a mean value of 2.78. However, the standard deviation of 0.84 reveals that the respondents did not vary in their responses. It is also evident that respondent were indifferent as to whether there was tolerance and women inclusiveness in all political activities in Nakuru County. This is also revealed by a mean value of 3.21. However, the standard deviation of 1.05 reveals that the respondents varied in their responses in regard to whether there was tolerance and women inclusiveness in all political activities in Nakuru County. Also, the respondents disagreed that women had a special responsibility to represent the needs and interests of women as revealed by a mean value of 1.97. However, a significant standard deviation of 0.89 under the same test revealed varied responses. The fact that women have a special responsibility to represent the needs and interests of women indicated that the level of women empowerment in the county has tremendously improved. However, it is evident that family obligations still made it difficult for women to plan their participation in leadership and economic activities as shown by a mean value of 3.11 although the standard deviation of 1.04 under the same test revealed that there was a great variation in the responses.

\subsubsection{Inferential Statistical Analysis}

The following section presents the inferential statistical analysis on data obtained from the study. Regression analysis was employed in data analysis. This section presents the results obtained from the inferential analysis of the relationship between devolution and women empowerment in Nakuru County. The indicators of devolution were Substantive Women Representation (SWR), Development of Programs (DOP) and Accessibility of Services (AOS). The relationship was established through regression analysis whose summary is presented in Table 6 .

Table 6: Regression Model Summary

\begin{tabular}{|c|c|c|c|c|c|c|c|c|c|}
\hline \multirow[t]{2}{*}{ Model } & \multirow[t]{2}{*}{$\mathrm{R}$} & \multirow{2}{*}{$\begin{array}{c}\mathrm{R} \\
\text { Square }\end{array}$} & \multirow{2}{*}{$\begin{array}{l}\text { Adjusted } \\
\text { R Square }\end{array}$} & \multirow{2}{*}{$\begin{array}{l}\text { Std. Error } \\
\text { of the } \\
\text { Estimate }\end{array}$} & \multicolumn{5}{|c|}{ Change Statistics } \\
\hline & & & & & $\begin{array}{c}\text { R Square } \\
\text { Change }\end{array}$ & $\begin{array}{c}F \\
\text { Change }\end{array}$ & $\mathrm{df}^{1}$ & $\mathrm{df}^{2}$ & $\begin{array}{c}\text { Sig. F } \\
\text { Change }\end{array}$ \\
\hline 1 & .887 & .786 & .783 & 1.2467 & .786 & 65.76 & 1 & 130 & .000 \\
\hline
\end{tabular}

The results in Table 6 show that there was a positive relationship between devolution and women empowerment $(\mathrm{r}=0.786)$. The adjusted $\mathrm{R}$ squared in the above model is the coefficient of determination which tells us the variation in the dependent variable due to changes in the independent variables. As shown the value of adjusted $R$ squared $\left(R^{2}\right)$ was 0.783 indicating that there was variation of $78.3 \%$ in women empowerment in Nakuru County due to Substantive Women Representation, Development of Programs and Accessibility of Services at $95 \%$ confidence interval. This shows that $78.3 \%$ changes in women empowerment was attributed to Substantive Women Representation, Development of Programs and Accessibility of Services brought about by Devolution in Nakuru County. As presented in the model, $\mathrm{R}$ is the correlation coefficient which shows the 
relationship between the study variables. Therefore from the findings shown in the Table 7 there was a strong positive relationship between the study variables as shown by 0.887 .

Table 7: Coefficients

\begin{tabular}{|l|l|c|c|c|c|c|}
\hline $\begin{array}{l}\text { Model } \\
1\end{array}$ & & \multicolumn{2}{|c|}{$\begin{array}{c}\text { Unstandardized } \\
\text { Coefficients }\end{array}$} & $\begin{array}{l}\text { Standardized } \\
\text { Coefficients }\end{array}$ & $\mathrm{t}$ & Sig. \\
\hline 1 & & $\mathrm{~B}$ & Std. Error & Beta & & \\
\cline { 2 - 7 } & Constant & .417 & .341 & & 1.638 & .003 \\
\cline { 2 - 7 } & $\begin{array}{l}\text { Substantive } \\
\text { Representation }\end{array}$ & .439 & .365 & .305 & 1.673 & .004 \\
\cline { 2 - 7 } & Development of Programs & .592 & .471 & .147 & 1.087 & .004 \\
\cline { 2 - 7 } & Accessibility of Services & .484 & .357 & .493 & 1.892 & .002 \\
\hline
\end{tabular}

From the data in the above table the established regression equation was

$$
\mathrm{Y}=0.417+0.439 \mathrm{X}_{1}+0.592 \mathrm{X}_{2}+0.484 \mathrm{X}_{3}
$$

From the above table of coefficients it is evident that that holding Substantive Women Representation, Development of Programs and Accessibility of Services to a constant zero, women empowerment would be 0.417(41.7\%). It also shows that the introduction of Substantive Women Representation influenced women empowerment in Nakuru County by a factor of 0.439 (43.9\%) while the introduction of development programs through devolution influenced women empowerment in Nakuru County by a factor of 0.592 (59.2\%). Similarly increased Accessibility of Services targeting women influenced women empowerment by a factor of $0.484(48.4 \%)$. The significance of the variables was supported by the values whose significance values were less than 0.05 which indicated that the independent variables were statistically significant in influencing women empowerment in Nakuru County.

\section{CONCLUSIONS}

The study concludes that substantive women representation has had a positive effect on the women empowerment in Nakuru County. Through substantive women representation women have had control and say on matters influencing social choices and decisions affecting the whole society. They have also been able to participate in political life had received support and commitment from men all of which have enlarged women's women empowerment in Nakuru County. The study concludes that through devolution there is development of programs which significantly influenced women empowerment. Programs such as uwezo funds have strengthened women's capacity to influence development oriented programmes. These programs have also been designed to enhance women participation in projects as they ppromoted tolerance and inclusiveness. It is evident that the introduction of development programs had the greatest impact on women empowerment in Nakuru County.

It is also concluded that through devolution, there were increased accessibility of services targeting women which consequently lead to women empowerment in Nakuru County. Accessibility of services promoted women empowerment as these services promoted women opportunies for access to education, healthcare and decent livelihoods as revealed

\section{RECOMMENDATIONS}

The study recommends that more programs targeting women should be introduced as these have the greatest impact on women. The county government should be able to expand the existing development programs such as women fund and uwezo fund so as to provide more opportunities for women empowerment. The study also recommends enhanced substantive representation approaches so as to improve the number of women representation in Nakuru County. Through substantive representation, women will be able to champion for the rights of women and development programs that are likely to empower them. In addition, more efforts need to be applied in addressing the challenges limiting the women access to services so that they can reap optimal benefits from the devolution. There is also need for all development stakeholders to ensure services targeting women so that more women can be involved in empowerment initiatives in Nakuru County and to ensure sustainability and availability of those services that have so far been realized through devolution.

\section{REFERENCES}

[1] Akapire, A. J., Awal, A. M., \& Fuseini, R. (2011). Catch them young: the young female parliament in Northern Ghana," in Participatory Learning and Action: Young citizens: youth and participatory governance in Africa, London: Citizens: youth and participatory governance in Africa, London. 
[2] Alsop, R. \& Heinsohn, N. (2005). Measuring Empowerment in Practice: Structuring Analysis and Framing Indicators. Washington, The World Bank. (Policy Research Working Papers , p. 510.

[3] Awuor, P. (2013). Gender Mainstreaming and Women Empowerment in Political Party Processes in Kenya: Implementing the New Constitution in Earnest. International Journal of Humanities and Social Science. Volume 3, Issue No.3;

[4] Bratton, K. A., \& Leonard, P. R. (2002). Descriptive Representation, Policy Outcomes, and Municipal Day-Care Coverage in Norway. American Journal of Political Science. Volume 46, Issue Number 2.

[5] Breton, Albert. (1996). Competitive Governments: An Economic Theory of Politics and Public Finance. Cambridge University Press.

[6] Caiazza, A. (2006). Called to Speak: Six Strategies That Encourage Women's Political Activism Lessons from Interfaith Community Organizing. Washington, DC: Institute for Women's Policy Research.

[7] Carroll, S. J. (1995). The Impact of Women in Public Office. Indiana University Press.

[8] Centre for Women and Democracy. (2011). Representative Democracy? Women. In the 2011 Local Government Elections in England. Leeds: CFWD.

[9] Committee on the Elimination of Discrimination against Women, (1997). General Recommendation No. 23 " on women in political and public life, adopted at the 16th Session. Geneva: CEDAW. UN Doc. $\mathrm{A} / 52 / 38$.

[10] Constitution of Kenya (CoK), (2010). Government Press, Nairobi, Kenya.

[11] Cornwall, A. \& Goetz, A. M. (2005). Democratizing Democracy: Feminist perspectives. Democratization, Volume 12(5)83-800. FIDA - Kenya (2010).

[12] Crone, T. (2010). Transforming the National AIDS Response Advancing Women's Leadership and Participation. New York: UNIFEM and ATHENA)

[13] Tanyang, G, (2009). Creating the space to empower women fishers: lessons from the Philippines. In Hoare, J. and Gell, F. (Eds). Women's Leadership \& Participation, Programme Insights. Oxford: Oxfam.

[14] Gilligan, C. (1982). In A Different Voice. Harvard University Press.

[15] Goetz, A. M. (2004). Decentralization and Gender Equality in UNDP. Striving for Gender Equality in an Unequal World, UNDP report for Beijing+10.

[16] Grown, C., Rao G, G., \& Khan, Z., (2005). Taking Action: Achieving gender Equality and Empowering Women. New York: UNDP (UN Millennium Project,Task Force on Education and Gender Equality.

[17] Hayek, F. (1945). The Use of Knowledge in Society. American Economic Review. Volume 35, p. 519-30.

[18] Hoare, J. \& Gell, F., (2009). Women's leadership and participation: case studies on learning for action. Oxford: Oxfam GB.

[19] Horner, L., \& Stokes, R. (2012). Advancing Equality in Women's Participation and Influence in Public Life through the Post-2015 Framework: Submission to the Global Thematic Consultations 'Addressing Inequalities'.

[20] Huggins, A., \& Randell, S. K. (2007). Gender Equality in Education in Rwanda: What is happening to our Girls?'A Paper presented at the South African Association of Women Graduates Conference on "Drop -outs from School and Tertiary Studies: What is Happening to our Girls?" Capetown, May, 2007.

[21] Hust, E. (2002). Political Representation and Empowerment: Women in the Institutions of Local Government in Orissa after the 73rd Amendment to the Indian Constitution. Heidelberg Papers in South Asian Comparative Politics. Working Paper No. 6, August.

[22] Institute of Economic Affairs (IEA) (2010). Research Paper, Series No. 24, "Devolution In Kenya: Prospects, Challenges and the Future," CInstitute of Economic Affairs.

[23] Institute of Economic Affairs (IEA). (2008). Profile of Women's Socio-Economic Status in Kenya. Nairobi: Institute of Economic Affairs.

[24] Inter-Parliamentary Union. (2013). Women in National Parliaments.

[25] Kabeer, N. (1999). Resources, Agency, Achievements: Reflections on the Measurement of Women's Empowerment. Development and Change. 30(3)435-464.

[26] Kamau, P. W. (2012). An assessment of political environment on public health facilities' response to devolution in Kenya: A survey of public health facilities in Nakuru County. Kenya Methodist University, Kenya. Unpublished research paper.

[27] Kang'ethe, N. (2007). Women and Leadership in Africa: A Case of Deviate or Die. In Kimani Njogu (ed). Governance and Development: Towards Quality Leadership in Kenya. Nairobi: Twaweza Communications.

[28] Mahwood, P. (1983). Local Government in the Third World, John Wiley \& Sons, Chichester.Meenakshisundaram, In S.S. (1994). Decentralization in Developing Countries. Concept Publishing, Bombay. 
[29] Meer, S., \& Sever, C. (2004). Gender and Citizenship: Overview Report (part of Cuting Edge Pack on.Gender and Citizenship). Brighton: Institute of Development Studies UK, BRIDGE DevelopmentGender.

[30] Ministry of Foreign Affairs Hoare, J. \& Gell, F., (2009). Women's leadership and participation: case studies on learning for action. Oxford: Oxfam GB.

[31] Mitullah, W. V., \& Owiti, L. A. (2007). Women and the Politics of Transition. In Wanyande, P., Omosa, M., and Chweya, L. (Eds), Governance and Transition Politics in Kenya.

[32] Musgrave, R. A. (1959). The Theory of Public Finance. McGraw-Hill: New York.

[33] Oates, K. (1999). Allocative Efficiency Theory. In Mueni, C. (2014).The impact of devolving finance functions in the counties in Kenya: A case study of Nakuru County headquarters. Jomo Kenyatta University for Agriculture and Technology, Kenya.

[34] Oduol, J. A. (2011). Women in Leadership and Governance. In Okoth Okombo, et al., (Eds) Challenging the Rulers: A Leadership Model for Good Governance. Nairobi: EAEP and Community Aid International, p. $160-180$.

[35] Ofei-Aboagye, E. (2000). Promoting the Participation of Women in Local Governance and development: the Case of Ghana. Paper prepared for seminar on "European Support for Democratic Decentralization and Municipal Development-A Contribution to Local Development and Poverty Reduction", Maastricht, 14-15 June. ECDPM and the Swedish.

[36] Omondi, G. (2010). The Student Movement and Youth Organisations in Kenya's Political Development: A RecentHistory. In Okoth Okombo (ed). Civil Society and Governance in Kenya since 2002: Between Transition and Crisis. Nairobi: ARRF and Heinrich Böll Stiftung, p. 113-134.

[37] Parkes, J., \& Heslop, J. (2011). Stop Violence Against Girls in School: A cross-country analysis of baseline research from Ghana, Kenya and Mozambique. London: IoE and ActionAid International.

[38] Pitkin, H. (1967). The Concept of Representation. University of California Press.

[39] Powley, E. (2004). Rwanda: Women Hold Up Half the Parliament. Women in Parliament: Beyond Numbers.

[40] Qian, Y. \& Weingast. B. (1997). Federalism as a Commitment to Preserving Market Incentives. Journal of Economic Perspectives. 11(4)83-92.

[41] Republic of Kenya (RoK). (2010b). The Constitution of Kenya. Nairobi: Government Printer.

[42] Republic of Kenya (RoK). (2011). The Political Parties Act 2011. Nairobi: Government Printer.

[43] Republic of Kenya (RoK). (June 2008): Training Manual in Gender Mainstreaming.

[44] Republic of kenya(RoK).( july 2011) ministry of gender, children and social development gender policy

[45] Sivi-Njonjo, K. (2010). Youth Fact Book: Infinite Possibility or Definite Disaster? Nairobi: IEA.

[46] Tiebout, C. (1956). A Pure Theory of Local Expenditures. Journal of Political Economy. Volume 64, p. 416-424.

[47] UN Women (2013). Facts and Figures: Leadership and Political Participation.

[48] UNESCO (2009). Priority Gender Equality. Action Plan 2008-2013. Paris: United Nations Educational, Scientific andCultural Organisation.

[49] UNESCO (2011). Education Counts: Towards the Millennium Development Goals. Paris: United Nations Educational, Scientific and Cultural Organisation.

[50] United Nations Secretary-General. (2012). Improvement in the status of women in the United Nations System. Report of the Secretary-General at the 67th General Assembly in New York, September.

[51] United Nations, (2013). The UN Millennium um Development Goals Report 2013.

[52] United Nations. (1997). Report of the Economic and Social Council for 1997. A/52/3, 18 September. United Nations.

[53] Unterhalter, E. (2011). How far does this go? Reflections on using the capability approach to evaluate gender, poverty, education and empowerment. A Talk prepared for CIES Gender committee symposium CIES Conference, Montreal, London: Institute of Education, University of London.

[54] Unterhalter, E., North, A. \& Parkes, J. (2010). Gender Equality and Women and Girls Education, 19952010: How much is there a space for hope? Paper for UNESCO 15 year Review of the Beijing Platform of Action. London: Institute of Education, University of London.

[55] WSP. (2008). The Elusive Quest for Women's Empowerment in Electoral Politics:A Synopsis of the 2007 Electoral Year. Rapid Assessment and Gender Audit of Electoral Processes in Kenya (Raga II). Nairobi: WSP/HIVOS

[56] Xiaoxian, G. (2010). From the Heyang Model to the Shaanxi Model: action research in village governance. The China Quarterly. 